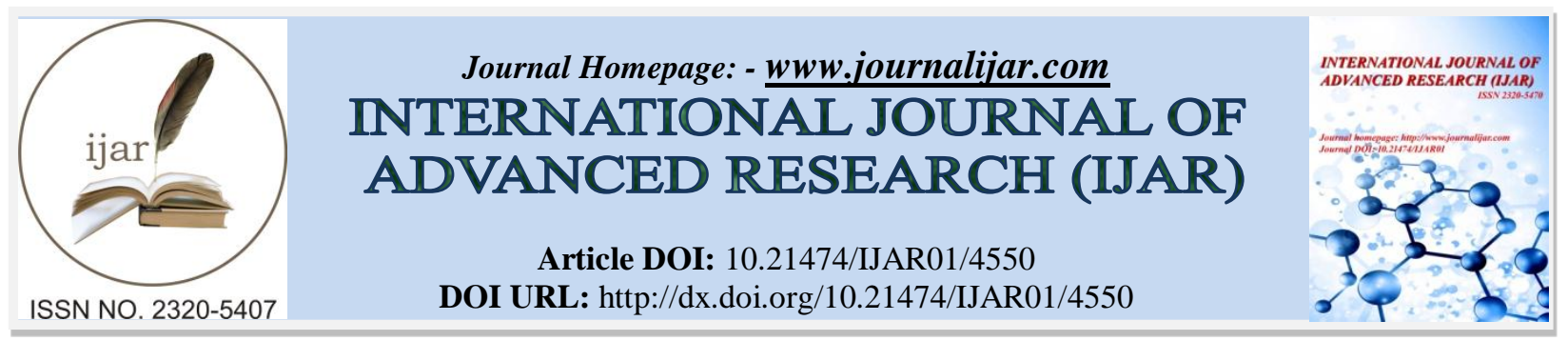

RESEARCH ARTICLE

\title{
AN ATTEMPT OF IN VIVO CULTIVATION OF CROCUS SATIVUS L. IN WESTERN MAHARASHTRA,
} INDIA.

\section{"Mohd. Shahnawaz ${ }^{1,8}$, Manisha Kashinath Sangale ${ }^{2,8}$, Hilal Ahmad Qazi ${ }^{3,8}$, Refaz Ahmad Dar", Tasadoq Hussain Jaweed ${ }^{5}$, Mohd. Yaseen Sirwal ${ }^{6}$, Romana Akhtar ${ }^{7}$, Mansoor Hussain Mattoo ${ }^{3}$, Abid Qayoom Tak ${ }^{3}$ and Avinash Bapurao Ade ${ }^{8}$.}

1. Department of Botany, Govt. Degree College Kishtwar, Kishtwar-182204, Jammu and Kashmir, India.

2. Department of Botany, Yashavantrao Chavan Institute of Science, Satara- 415001, Maharashtra, India.

3. Department of Botany, University of Kashmir, Hazratbal, Srinagar-190006, Jammu and Kashmir, India.

4. Biotechnology Division, Indian Institute of Integrative Medicine (Council of Scientific and Industrial Research) Sanatnagar, Srinagar, Jammu and Kashmir, India.

5. Department of Environmental Sciences, Savitribai Phule Pune University, Pune-411007, Maharashtra, India.

6. Department of Chemistry, Govt. Degree College Kishtwar, Kishtwar-182204, Jammu and Kashmir, India.

7. Department of Zoology, Govt. Degree College Kishtwar, Kishtwar-182204, Jammu and Kashmir, India.

8. Department of Botany, Savitribai Phule Pune University, Pune-411007, Maharashtra, India.

\section{Manuscript Info}

Manuscript History

Received: 20 April 2017

Final Accepted: 22 May 2017

Published: June 2017

Key words:-

C. sativus, Crocins, Picrocrocin,

Safranal, in vivo cultivation
Abstract

Crocus sativus L. is one of the most precious plant of the world. Its flower contains three key components such as crocins, picrocrocin and safranal. Since ancient times C. sativus is widely being used as medicine, spice and food colorant around the globe. It propagates through rhizomes. It is usually being cultivated in few countries of the world. In the present study an attempt has been made to grow the rhizomes of $C$. sativus collected from Kishtwar (temperate region) in the Botanical Garden of the Department of Botany, Savitribai Phule Pune University, Pune (sub-tropical region). During the study, most of the rhizomes grow well, but the flowering stage was not reported. The variation in environmental factors could be the possible reason for this flower less stage of the C. sativus.

Copy Right, IJAR, 2017,. All rights reserved.

\section{Introduction:-}

Crocus sativus L. is regarded as the most precious and expensive spice of the world (Abdullaev et al., 1992; Abdullaev, 1993). For food colorant and spice the dry stigmas of C. sativus L. are being used (Abdullaev et al., 1992; Aguero and Tizio, 1994; Ait-Oubahou et al., 1999). The annual production of saffron is 50 tons worldwide having worth of about 50 million dollars (Negbi, 1999). More than 150 volatile and aroma-yielding compounds are reported in C. sativus (Abdullaev, 2002). It is also reported to have many non-volatile active components, many of which are carotenoids, including zeaxanthin, lycopene, and $\alpha$ and $\beta$ carotenes (Abdullaev, 2002). Since ancient civilization its therapeutic medicinal benefits are well recognized (Rois et al., 1996; Ferrence and Bendersky, 2004). In recent years, based on water soluble carotenoids, its therapeutic value in certain cancers, cerebrovascular and cardiovascular diseases has been well documented (Nair et al., 1991; Abdullaev and Frenkel, 1992; Abdullaev, 1993; Rois et al., 1996). C. sativus contains three principal components such as crocins, picrocrocin and safranal (Rios et al., 1996). Crocin is a long chain of highly unsaturated and conjugated tetraterpenes responsible for the 
colour of stigma. Five types of crocins ranging from crocin-1 to crocin-5 are reported to be present in the $C$. sativus and its other species (Trantilis et al.,1995). The picrocrocin is responsible for bitterness and odour of the saffron and is used in flavoring (Zarghami and Heinz, 1971; Visvanath et al., 1990; Auria et al., 2006). All these principal active compounds are expressed in the stigma of C. sativus (Bouvier et al., 2003; Morga et al., 2004).

The cultivation of $C$. sativus L. has decreased steadily and is about to disappear in some traditional producing countries (Visvanth et al., 1990; Chen et al., 2004; Molaina et al., 2005). The method adopted for production of saffron includes, hand picking of stigma after the plant has bloomed followed by shade drying. The current traditional method for saffron cultivation is inefficient, results its low agricultural production, which is considered as one of the main reason for its high market price. Rate of generation of daughter corms under natural conditions is low (Jirage et al., 1994; Chahota et al., 2003). The propagation of bulbs of $C$. sativus is not easy, so its propagtivity is low (Jirage et al., 1994, Chahota et al., 2003, European patent application, 1987). In saffron to produce propagating material at commercial scale, micro-propagation technique can be used, however to achieve this goal, no efficient protocols are available (Plessner and Ziv, 1999). Using explants of various ranges such as callus cultures, terminal buds, lateral buds, small corms and ovaries of $C$. sativus. Although shoot regeneration of $C$. sativus has been achieved, but its frequency remained very low (Ding et al., 1979, 1981; Isa and Ogasawara 1988; Plessner et al.,1990; Aguero and Tizio 1994; Milyaeva et al., 1995, Piqueras et al., 1999; Bhagyalakshami 1999; Karamian, 2004; Blazquez et al., 2004). Therefore, the very poor establishment of plantlets in the field and low frequency of cormlet induction from tissue culture derived shoots are the major problems in the micropropagation of saffron (Milyaeva et al., 1995). According to Wani and Mohiddin (2009), out of twenty reports of tissue culture on saffron only Milyaeva et al. (1995) and Sheibani et al. (2007) reported in vivo growth of plants after passing in vitro stage. In order to lower down the price of saffron, it is needed to be cultivated at large scale, for which specific land for saffron cultivation should be identified besides the earlier reports. It was hypothesized that, as saffron grows well in the Morocco having maximum temperature $45^{\circ} \mathrm{C}$ and annual average rainfall between 100 to $300 \mathrm{~mm}$ (AitOubahou and El-Otmani, 1999), so it may be highly possible to grow such a plant in vivo in the city like Pune having moderate climate. In the present study an attempt was made to cultivate the C. sativus in the Botanical garden, Department of Botany, Savitribai Phule Pune University Pune, Pune-411007, Maharashtra, an institution located in a subtropical region of Western India.

\section{Material and methods:-}

Collection of the rhizomes:-

The rhizomes of $C$. sativus were collected from the village Poochal of the District Kishtwar-182204, Jammu and Kashmir State, India. The collection was done during the month of September 2010.

\section{Planting $C$. sativus at the native place in a pot:-}

A plastic pot was filled with the soil at Sadeeqabad Link Road, Kishtwar. The rhizomes were sown in the month of October 2010 as per the instructions by the local farmers. The pots were kept under open field and watered once a week.

\section{Designing of the experiment:-}

The randomized design of the experiment was used throughout the study. At each place (open field, green house and glass house) three pots were kept.

\section{Preparation of the pots:-}

The black soil of Botanical Garden, Department of Botany, Savitribai Phule University of Pune, Pune-411007, Maharashtra, India was used for the cultivation of $C$. sativus rhizomes. The sun dried soil was filled in the pots.

\section{Sowing of rhizomes:-}

In each dried soil filled pot, 6 rhizomes were sown as per the instruction by the local farmers of the Kishtwar vale. Total numbers of pots were nine (three for each set).

Watering:-

Watering was done every alternate day, during the morning hours. 

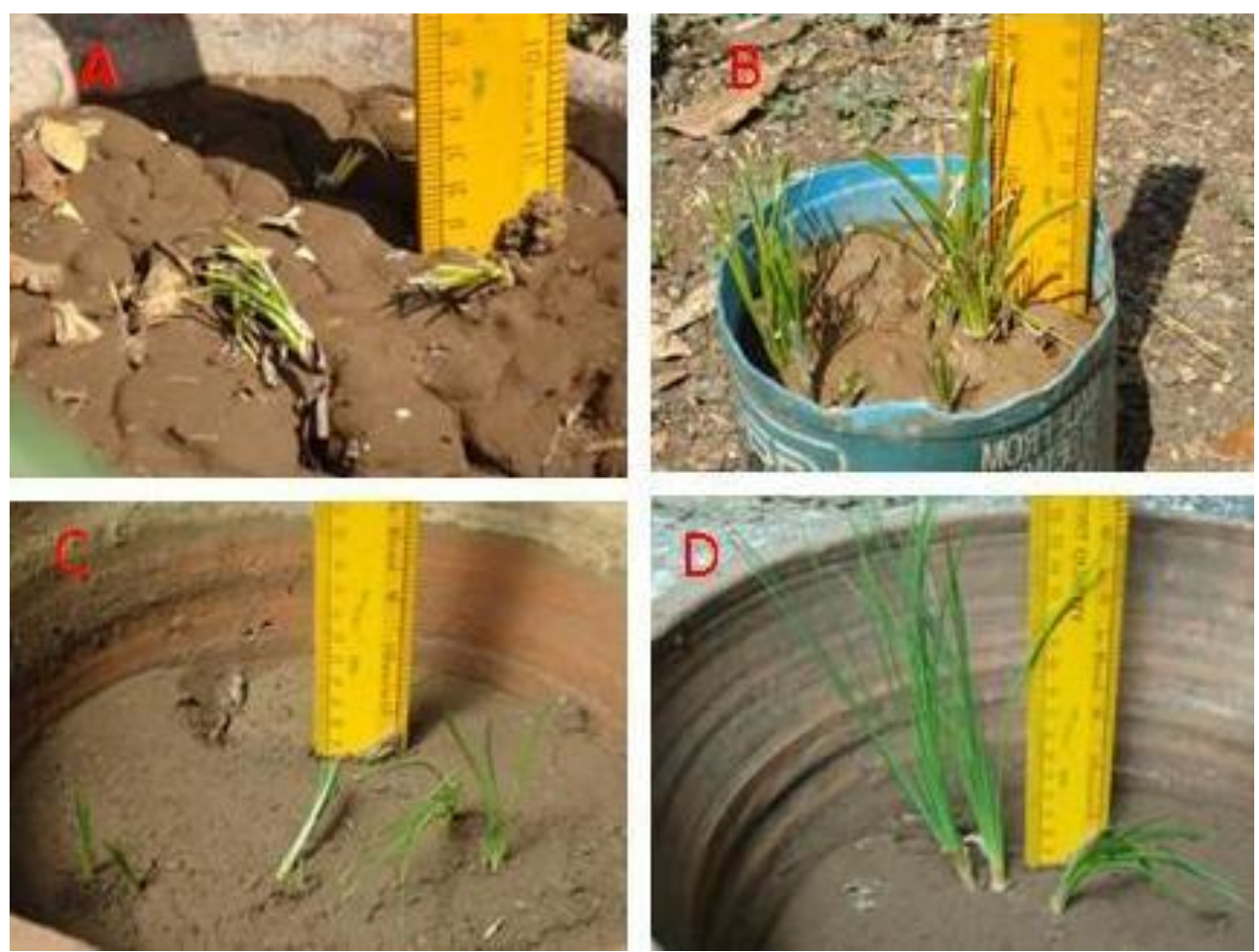

Fig 1:- Growth stages of C. sativus at different sites of Botanical garden, Department of Botany, Savitribai Phule Pune University, Pune: A: showing rhizome growth in green house after $50^{\text {th }}$ days of sowing, B: showing $60^{\text {th }}$ day of rhizome growth in open field (transferred from Kishtwar), C: showing rhizome growth in open field of Botanical

Garden after $50^{\text {th }}$ and D: showing rhizome growth in palm house/glass house after $50^{\text {th }}$ days of sowing.

\section{Results and discussion:-}

The detailed growths of rhizomes for $C$. sativus are given in the Fig. 1. A great variation in the growth of $C$. sativus was observed among three sites of its cultivation. It was found that in glass house set after $40^{\text {th }}$ and $50^{\text {th }}$ day of sowing only 2 and 3 rhizomes sprouted. Whereas the rhizomes sown in the open field did not grow well. The best growth of the $C$. sativus was found in the pots which were placed in the glass/palm house. But the flowering stage was not witnessed even after the proper growth of the plant during the study.

Until 2016, there were no reports of $C$. sativus in vivo cultivation in Maharashtra. In 2010-2011 we tried to cultivate C. sativus in Pune based on the reason that it is being cultivated in Morocco having maximum temperature $45^{\circ} \mathrm{C}$ (Ait-Oubahou, and El-Otmani, 1999). Since the climatic conditions of Pune city are somewhat similar to that of Morocco. We were successful in establishing normal vegetative growth of these plants but failed to achieve its flowering stage. The possible reason for this could be other environmental factors. Recently Dr. C. K. John, a Senior Scientist from Biochemical Sciences Division, CSIR-National Chemical Laboratory, Pune got success in getting the flowering in Kashmir based C. sativus in green house using the ice chilled treatment of the rhizomes (John, 2017).

Thus, there is immediate need for rigorous study on this economically important plant for its wide spread cultivation in the region with sub-tropical climate.

\section{Acknowledgement:-}

All authors are highly indebted to Mr. and Mrs. Abdul Qayoom Zarger, resident of Paenhaar, Poochal, Kishtwar for providing the $C$. sativus rhizomes to carry out the present study. MS is thankful UGC-BSR and UGC-MANF for financial support in the form of JRF and SRF. MKS is indebted to UGC-BSR for providing the fellowship (JRF). HAQ is thankful to DAE-BRNS (for JRF and SRF) and DST-SERB for financial assistance (for Fast Track Young Scientist Award). 


\section{References:-}

1. Abdullaev FI. Biological Effects of Saffron. Biofactors.1993; 4: 83-86.

2. Abdullaev FI. Cancer Chemopreventive and Tumoricidal Properties of Saffron (C. sativus L.). Exp. Biol. Med. 2002; 227(1):20-25.

3. Abdullaev FI, Frenkel GD. The Effect of Saffron on Intracellular DNA, RNA and Protein Synthesis in Maligant and Non-maligant Human Cells. Biofactors. 1992; 4: 43-45.

4. Aguero C, Tizio R. In Vitro Mass Bulbification as a Preliminary Contribution to Saffron (Crocus sativus L.), Biocell. 1994; 18: 55-63.

5. Ait-Oubahou A, El-Otmani M. Saffron Cultivation in Morocco. In: Negbi, Moshe editor, Saffron Crocus sativus L. Harwood Academic Publications, Amsterdam, Netherlands; 1999. p. 87-94.

6. Auria DM, Mauriello G, Racioppi R, Rana GL. Use of SPME- GC-MS in Study of Time of Evolution of Constituents of Saffron Aroma: Modification of the Composition during Storage. J. Chromatographic Sci. 2006; 44: $18-21$.

7. Bhagyalakshmi N. Factors Influencing Direct Shoot Regeneration From Ovary Explants of Saffron, Plant Cell Tissue Organ Cult. 1999; 58: 205-211.

8. Blazquez S, Olmos E, Hernandez JA, Hellin E, Fernandez JA, Piqueras A. Somatic Embryogenesis in Saffron (Crocus sativus L.): Morphological Differentiation and the Role of the Antioxidant Enzymatic System, Acta Hort. 2004; 650: 261-267.

9. Bouvier F, Suire C, Mutterer J, Camara B. Oxidative Remodeling of Chromoplast Carotenoids: Identification of the Carotenoid Dioxygenase CsCCD and CsZCD Genes Involved in Crocus Secondary Metabolite Biogenesis. The Plant Cell. 2003; 15: 7-62.

10. Chahota RK, Dhiman KC, Rana SS, Singh M. Efficacy of Different Propagating Methods for Higher Daughter Corm Production in Saffron (Crocus sativus L.), Indian Perfumer. 2003; 47: 155-158.

11. Chen S, Zhao B, Wang X, Yan X, Wang Y. Promotion of the Growth of Crocus sativus Cells and the Production of Crocin by Rare Earth Elements, Biotechnol. Lett. 2004; 26: 27-30.

12. Ding B, Bai SH, Wu Y, Fang XP. Induction of Callus and Regeneration of Plantlets from Corms of Crocus sativus L., Acta. Bot. Sin. 1981; 23: 419-420.

13. Ding B, Bai SH, Wu Y, Wang BK. Preliminary Report on Tissue Culture of Corms of Crocus sativus. Acta. Bot. Sin. 1979; 21: 387.

14. European patent application, (1987) Stigmas of Crocus sativus L. and Methods For The Production Thereof, Sano, Konosuke Central Research Laboratories, Ajinomoto Cop., Inc. no.1-1, Suzuki-Cho, Kawasaki-Ku Kawasaki-Shi Kangawa-Ken (JP), Publication number 0233040, pp.1-16

15. Ferrence SC, Bendersky G. Therapy with Saffron and the Goddess at Thera. Perspect. Biol. Med. 2004; 47:199226

16. Isa T, Ogasawara T. Efficient Regeneration From the Callus of Saffron (Crocus sativus L.), Japan J. Breed. 1988; 38: 371-374.

17. Jirage D, Ravishankar G, Suvarnlatha G, Venkataraman L. Production of Polyamines During Sprouting and Growth of Saffron (Crocus sativus L.) corms, Plant Growth Regul. 1994; 13: 69-72.

18. John CK (2017) CSIR-National Chemical Laboratory grows Saffron in a greenhouse, http://www.nclindia.org/files/DisplayResource.aspx?ResourceId=a751d0a4-a2af-4925-b458-02aea9cc0997\&OriginalFile Name=PR_0501.pdf (accessed on 28 ${ }^{\text {th }}$ May 2017).

19. Karamian R. Plantlet Regeneration Via Somatic Embryogenesis in Four Species Of Crocus, Acta Hort. 2004; 650: 253-259.

20. Milyaeva EL, Azizbekova NS, Komarova EN, Akhundova DD. In-Vitro Formation of Regenerant Corms of Saffron Crocus (Crocus sativus L.), Russ. J. Plant Physiol. 1995; 42: 112-119.

21. Molina RV, Valero, M, Navaroo Y, Guardiola JL, Guardiola A L. Temperature Effects on Flower Formation in Saffron (Crocus sativus L.) J. Hortic. Sci. Biotechnol. 2005; 80: 319-326.

22. Morga AR, Lopez RC, Gomez LG, Ahrazem O. Saffron is a Monomorphic Species as Revealed by RAPD, ISSR and Microsatellite Analysis. BMC Res. Notes. 2004; 2: 189.

23. Nair SC, Pannikar B, Pannikar KR. Antitumour Activity of Saffron (Crocus sativus). Cancer Lett. 1991; 57: 109-114.

24. Negbi M. Saffron Cultivation: Past, Present and Future Prospects. In: Negbi M. editors. Saffron Crocus sativus L. Harwood Academy Publication., Amsterdam, Netherland; 1999. p. 19-30.

25. Piqueras A, Han BH, Escribano J, Rubio C, Hellin E, Fernandez JA. Development of Cormogenic Nodules and Microcorms by Tissue Culture, a New Tool for the Multiplication and Genetic Improvement of Saffron, Agronomie. 1999; 19: 603-610. 
26. Plessner O, Ziv M. In vitro Propagation and Secondary Metabolite Production in Crocus sativus L. In: Medicinal and Aromatic Plants-Industrial. Harwood Academic publishers, Amsterdam, Netherlands; 1999. p. 137-148.

27. Rois JL, Recio MC, Giner RM, Manez S. An Update Review of Saffron and its Active Constituents. Phytotherapy Res. 1996; 10: 189-193.

28. Sheibani M, Nemati SH, Davarinejad GH, Azghandi AV, Habashi AA. Induction of Somatic Embryogenesis in Saffron Using Thidiazuron (TDZ). Acta Hortic. 2007; 739: 259-268.

29. Tarantilis PA, Tsoupras G, Polissiou M. Determination of Saffron (Crocus sativus L.) Components in Crude Plant Extracts Using High-Performance Liquid Chromatography-UV-Vis Photodiode-Array Detection-Mass Spectrometry. J. Chromatogr. 1995; 699 (1): 107-117.

30. Visvanath S, Ravishankar GA, Venkataraman LV. Induction of Crocin, Crocetin, Picrocrocin and Saffaranal Sysnthesis in Callus Cullutre of Saffron- Crocus sativus L. Biotech., Appl. Biochem. 1990; 12: 336-340.

31. Wani BA, Mohiddin FA. Micropropogation of Genus Crocus: A Review. AJAR. 2009; 4(13): 1545-1548.

32. Zarghami NS, Heinz DE Monoterpene Aldehydes and Isophorone- Related Compounds of Saffron. Phytochemistry, 1971; 10: 2755-2760. 